\title{
The IGF Pathway in Gynecology Oncology- Current Knowledge and Possible Therapeutic Implementations
}

\author{
Anna Blecher ${ }^{1}$, Gabi Haran ${ }^{1}$, Yana Brudner ${ }^{1}$ Shilhav Meisel-Sharon ${ }^{1}$, Rive Sarfstein ${ }^{2}$, Mordehai Hallak ${ }^{1}$, Haim \\ Werner $^{2}$ and Ilan Bruchim ${ }^{1 *}$ \\ ${ }^{1}$ Gynecological Oncology Division, Hillel Yaffe Medical Center, Israel \\ ${ }^{2}$ Department of Human Molecular Genetics and Biochemistry, Tel Aviv University, Israel
}

Submission: May 01, 2017; Published: May 30, 2017

*Corresponding author: : : Ilan Bruchim, Gynecological Oncology Division, Hillel Yaffe Medical Center, Hadera, Hadera 38100, Israel, Tel: 972-4-6304515; Fax: 972-4-630-4948; Email:ilan.bruchim@gmail.com

\section{Abstract}

Over the last 20 years, accumulating evidence has identified the IGF axis as an important player in the carcinogenesis of several human malignancies including endometrial and serous ovarian carcinomas.

The IGF system comprises the ligands (IGF-1, IGF-2), cell surface receptors (IGF1R, IGF2R) and at least six IGF binding proteins (IGFBPs) and is coupled to several intracellular messenger pathways including the RAS-RAF-MAPK and PI3K. The IGF1R expression and activation was shown to be a fundamental prerequisite for acquisition of a malignant cell phenotype. IGF1R expression was shown to be significantly higher in endometrial carcinoma than in normal endometrium. Furthermore, several factors appear to negotiate their effect on endometrial growth and proliferation through the effect on IGF1R expression, including steroid hormones, hyper insulinemia and tumor suppressor genes such as p53 and BRCA. Interestingly, treatment with metformin (an oral anti hyperglycemic agent) was recently shown to prevent endometrial cancer through down regulation of the IGF axis. In the ovary, the IGF1R has been shown to be responsible for surface epithelial proliferation and administration of IGF1 was shown to stimulate ovarian carcinoma cell growth. IGF1R expression was found to be significantly higher in malignant than benign tumors and several IGFBPs levels were consistently different in patients with malignant tumors compared to controls. In addition, numerous studies demonstrated that hyperactivation of the IGF1R signaling pathway is important in ovarian cancer cell resistance to chemotherapy. IGF axis targeted treatment such as anti-IGF1R antibodies have shown significant promise in in-vitro studies and are being investigated in clinical studies.

Keywords: IGF; Ovarian carcinoma; Endometrial carcinoma; Cell growth; Therapies; Chemotherapies

Abbreviations: IGF: Insulin-Like Growth Factor; IGFBPs: IGF Binding Proteins; IGF1R: IGF 1 Receptor; MAPK: Mitogen-Activated Protein Kinases; PCOS: Polycystic Ovary Syndrome; TKIs: Tyrosine Kinase Inhibitors; EOC: Epithelial Ovarian Cancer; siRNA: Small Interfering RNA

\section{Introduction}

The IGF system has a regulatory effect on many cellular pathways and physiological processes including metabolic, nutritional, endocrine, growth and aging events. Accumulated evidence in the last 20 years identified the IGF axis as an important player in the carcinogenesis of several human malignancies including gynecologic malignancies, primary the endometrial and serous ovarian carcinomas [1]. The IGF system comprises the ligands (IGF-1, IGF-2), cell surface receptors (IGF1R, IGF2R) and at least six IGF binding proteins (IGFBPs) [2], serving as IGF's serum carrier and regulating the tissue effects of the IGFs by binding and preventing their access to the cell surface receptors
[3]. The IGFs exert their activities primarily through the IGF1R which is coupled to several intracellular messenger pathways including the RAS-RAF-MAPK and PI3K signaling cascades and signals mitogenic, antiapoptotic and transforming activities. In fact, several studies have shown that IGF1R expression and activation is a fundamental prerequisite for acquisition of a malignant phenotype, as cells with a disrupted IGF1R cannot be transformed by a number of oncogenes and on the other hand exogenous overexpression of IGF1R in cells results in tumor progression [1]. 


\section{IGF Axis in Carcinogenesis}

\section{IGF axis in endometrial carcinoma}

In normal endometrium cyclic changes in IGF-1 expression and signaling play key role in regulating the transition of the premenopausal endometrium through the proliferative, secretory and menstrual cycles and it has been identified as a major mediator of the effects of estradiol on uterine growth [4]. The IGF1R expression is significantly higher in endometrial carcinoma than in normal endometrium [5]. However, the association between serum IGF1 levels and endometrial cancer and its diagnostic or prognostic value is unclear, perhaps due to involvement of additional factors that can positively in negatively impinge upon IGF axis components [6-9].

Several risk factors for the development of endometrial hyperplasia and carcinoma such as unopposed estrogen, obesity, hyperinsulinemia, diabetes and PCOS, actually mediate their effects, at least partially, thought the IGF system [10,11]. IGF1 and IGFBP1 gene expression were found to be significantly up-regulated in the endometrium of PCOS and endometrial carcinoma compared to controls [12] and the degree of IGF1R over-expression in endometrial carcinoma cells increased as MBI increased [13]. Estrogen has been shown to stimulate the proliferation of uterine endometrium via activation of the IGF1R, while downstream activation of the IGF mediated pathway could play a major role in the progression to ER-independent tumors [14]. Increased androgens, a mainstay in PCOS, induce IGF1R upregulation [15] and hyperinsulinemia down regulates hepatic IGFBP-1, resulting in elevated free IGF-1 in the circulation [16]. Moreover, higher phosphorylated IGF1R were observed in diabetic vs non diabetic postmenopausal women [17]. Thus IGF axis seems to have an important part in the linkage of metabolic syndrome and endometrial cancer.

P53, a known tumor suppressor gene involved in carcinogenesis of several tissues including uterine cancer, has been linked to the IGF axis as well. It has been shown that p53 regulates IGF1R gene expression in endometrial cancer via repression of the IGF1R promoter. Pathologic deregulation if IGF1R gene expression as a result of tumor-specific, loss-offunction p53 mutations may lead to increased cell surface IGF1R concentrations and enhanced IGF1R phosphorylation by IGFs [18]. BRCA1, another important tumor suppressor gene, was shown to inhibit IGF1R transcription in endometrial carcinoma as well [19-21].

The IGF axis was recently implemented in the mechanism of anticancer activity of metformin on endometrium. Metformin demonstrates significant antiproliferative activity on endometrial cancer cells and enhance the sensitivity of those cells to chemotherapy [22-24] and several studies have shown that its action is mediated through down-regulation of the IGF1R and IGF1 expression [25-27].

\section{The IGF axis in ovarian carcinoma}

In the ovary, the IGF1R has been shown to be responsible for surface epithelial proliferation and ovarian epithelial carcinogenesis [28] and administration of IGF1 was shown to stimulate ovarian carcinoma cell growth [29]. A majority of human studies revealed high IGF and IGF1R expression in ovarian carcinoma cells compared to borderline and benign tumors and normal ovarian tissue and a positive correlation between their expression levels and ovarian cancer cell proliferation and invasiveness in vitro [1,30-32]. Some of these studies showed a correlation between IGF1R over expression with more advanced disease and worse clinical prognosis [33-35].

The clinical correlation between the serum levels of IGFs and cancer risk or prognostic factors, as in endometrial carcinoma, is inconclusive. Several studies have found high circulating IGF1 levels to be a risk factor for developing ovarian cancer, some have found an inverse correlation and some haven't found any correlation at all [36-43]. In a recent systematic review and meta-analysis, a significantly lower serum IGF1 levels were seen in ovarian cancer patients than in controls [44]. In addition, numerous studies demonstrated that hyperactivation of the IGF1R signaling pathway is an essential event in ovarian cancer cell resistance to chemotherapy [45-48].

As mentioned previously, the IGFBPs play an important role in the IGF signaling pathway. IGFBP-2 has been consistently shown to be over-expressed in malignant ovarian cancer and has a possible role in the aggressive and invasive behavior of these tumors. High IGFBP-2 tissue expression correlates positively with serum levels, clinical features and prognosis [49-56]. The information concerning IGFBP-3 is less conclusive. Tissue IGFBP-3 levels were shown to be higher in less aggressive tumors and low tissue IGFBP-3 levels were associated with unfavorable prognostic feature. Serum IGFBP-3 levels were shown to be decreased in patients with ovarian cancer compared to those of patients with benign tumors and controls and high serum IGFBP-3 was usually associated with better prognosis [57-59]. The logical explanation for this is that IGFBP-3 is the major IGF1binding protein in the serum, thus causing a reduction in free IGF1 levels. Hence, IGFBP-3 is considered anti-proliferative and pro-apoptotic.

\section{Anti-IGF treatments in gynecologic malignancies}

Based on accumulating preclinical and clinical data implicating the IGF axis in cancer biology multiple studies have evaluated more than 30 drugs targeting the IGF1R pathway, including anti-IGF1R antibodies, tyrosine-kinase inhibitors (TKIs) and antibodies against IGF1 and IGF2 ligands and IGF1R inhibitors showed the highest activity [5]. More than ten IGF/ IGF1R inhibitors have entered clinical studies and showed sustained response in a small number of patients with select tumor types but many large clinical trials involving patients 
with adult tumors, including non-small cell lung, breast and pancreatic cancers failed to show clinical benefit in the overall patient population $[60,61]$. In ovarian cell lines these treatments caused significant inhibition of tumor growth and proliferation, induced apoptosis and sensitized cells to chemotherapeutic agents [18,24,56-60,62]. A similar effect was shown in regard to endometrial cancer [63-65]. Several clinical trials involving IGF1R targeted therapies are currently under way.

\section{Discussion and Conclusion}

The IGF network has an important role in normal physiology of endometrium and ovary and has been shown to participate in ovarian epithelial and endometrial cell proliferation. Over expression of IGF axis components was consistently identified in ovarian and endometrial cancer tissues and in vitro studies have shown a causative linkage between dis-regulated expression and activation of the IGF axis and cancer cell proliferation and other hormonal and genetic factors have been shown to negotiate their effects on cancer risk through regulation the IGF axis. Some of the treatments that have shown anticancerous activity as metformin seem to work by regulating the IGF system. Multiple in vitro studies in endometrial and ovarian cancer have shown a positive effect of the IGF targeted therapies on cancer cells including decreased proliferation and tumor growth, increased apoptosis and increased sensitivity to chemotherapies. The clinical effect of these substances in the gynecologic malignancies is still to be proven since studies in other malignancies showed a low clinical effect of IGF axis inhibitors.

\section{Conflict of Interest}

His study was not supported by external funding.

\section{References}

1. Werner H, Bruchim (2009) The insulin-like growth factor 1 receptor as an oncogene. Arch Physiol Biochem 115(2): 58-71.

2. Weroha SJ, Hlauska $P(2012)$ The insulin like growth factor system in cancer. Endocrinol Metab Clin North Am 41(2): 335-350.

3. Wang HS, Chard T (1999) IGFs and IGFBPs in the regulation of human ovarian end endometrial function. J Endocrinol 161(1): 1-13.

4. Bruchim I, Sarfstein R (2014) The IGF hormonal network in endometrial cancer: functions, regulation, and targeting approaches. Frontiers of endocrinology.

5. Flannery CA, Saleh FL, Choe GH, Selen DJ, Kodaman PH, et al. (2016) Differential expression of IR-A, IR-B and IGF1R in endometrial physiology and distinct signature in adenocarcinoma. J Clin Endocrinol Metab 101(7): 2883-2891.

6. Ayabe T, Tsutsumi O, Sakai H, Yoshikawa H, Yano T, et al. (1997) Increased circulating levels of insulin-like growth factor- 1 and decreased circulating levels of insulin like growth factor binding protein1 in postmenopausal women with endometrial cancer. Endocr J 44(3): 429-424.

7. Petridou E, Koukoulomatis P, Alexe DM, Voulgaris Z, Spanos E, et al. (2003) Endometrial cancer and the IGF system: a case control study in Greece. Oncology 64(4): 341-345.
8. Gunter MJ, Hoover DR, Yu H, Wassertheil-Smoller S, Manson JE, et al (2008) A prospective evaluation of insulin and insulin like growth factor-1 as risk factors for endometrial cancer. Cancer Epidemiol Biomarkers Prevb 17(4): 921-929.

9. Weiderprass E, Brismar K (2003) Serum levels of insulin like growth factor-1, IGF-binding proteins 1 and 3 and insulin and endometrial cancer risk. Br J Cancer 89: 1697-1704.

10. Soliman PT, Wu D, Tortolero-Luna G, Schmeler KM, Slomovitz BM, et al. (2006) Association between adiponectin, insulin resistance and endometrial carcinoma. Cancer 106(11): 2376-2381.

11. Calle EE, Kaaks R (2004) Overweight, obesity and cancer: epidemiological evidence and proposed mechanisms. Nat Rev Cancer 4(8): 579-591.

12. Shafiee MN, Seedhouse C, Mongan N, Chapman C, Deen S, et al. (2016) Up-regulation of genes involved in the insulin signaling pathway (IGF1, PTEN and IGFBP1) in the endometrium may link polycystic ovarian syndrome and endometrial cancer. Mol Cell Endocrinol 15(424): 94-101.

13. Joehlin-Price AS, Stephens JA, Zhang J, Backes FJ, Cohn DE, et al (2016) Endometrial cancer insulin-like frowth factor-1 receptor (IGF1R) expression increases with body mass index and is associated with pathologic extent and prognosis. Cancer Epidemiol Biomarkers Prev 25(3): 438-445.

14. Zhu L, Pollard JW (2007) Estradiol regulates mouse uterine epithelial cell proliferation through insulin like growth factor 1 signaling. Proc Natl Acad Sci USA 104(40): 15847-15851.

15. Pandini G, Mineo R, Frasca F, Roberts CT, Marcelli M, et al. (2005) Androgens up-regulate the insulin-like growth factor-1 receptor in prostate cancer cell. Cancer Res 65(5): 1849-1857.

16. Giudice LC (2006) Endometrium in PCOS: Implantation and predisposition to endocrine CA. Best Prcat Res Clin Endocrinol Metab 20(2): 235-244.

17. Merritt MA, Strickler HD, Einstein MH, Yang HP, Sherman ME, et al. (2016) Insulin/IGF and sex hormone axis in human endometrium and associations with endometrial risk factors. Cancer Causes Control 27(6): 737-748.

18. Attias-Geva Z, Bentov I, Dvora Kidronb, Keren Amichayc, Rive Sarfstein, et al. (2012) P53 regulates insulin-like growth factor 1 receptor gene expression in uterine serous carcinoma and predicts responsiveness to an insulin-like growth factor-1 receptor mediated targeted therapy. Eur J Cancer 48: (10): 1570-1580.

19. Maor SB, Abramovitch S, Erdos MR, Brody LC, Werner H (2000) BRCA1 suppresses insulin like growth factor-1 receptor promoter activity: potential interaction between BRCA1 and sp-1. Mol Genet Metab 69(2): 130-136.

20. Abramovitch S, Glaser T, Werner H (2003) BRCA1-Sp1 interactions in transcriptional regulation of the IGF1R gene. FEBS lett 541(1-3): 149-154.

21. Abarmovich S, Werner H (2003) Functional and physical interactions between BRCA1 and P53 in transcriptional regulation og the IGF1R gene. Horm Metab Res 35: 758-762.

22. Cantrell LA, Zhou C, Mendivil A, Malloy KM, Gehrig PA, et al (2010) Metformin is a potent inhibitor of endometrial cancer cell proliferation - implications for a novel treatment strategy. Gynecol Oncol 116(1): 92-98.

23. Dong L, Zhou Q, Zhang Z, Zhu Y, Duan T, et al. (2012) Metformin sensitizes endometrial cancer cells to chemotherapy by repressing glyoxalase 1 expression. J Obstet Gynaecol Res 38(8): 1077-1785. 
24. Hanna RK, Zhou C, Malloy KM, Sun L, Zhong Y, et al. (2012) Metformin potentiates the effects of paclitaxel in endometrial cancer cells through inhibition of cell proliferation and modulation of the m-TOR pathway. Gynecol Oncol 125(2): 458-469.

25. Sarfstein R, Friedman Y, Bruchim I, Werner H (2013) Metformin down regulates the insulin/IGF-1 signaling pathway and inhibits different uterine serous carcinomas (USC) cells proliferation and migration in p-53 dependent and independent manners. PLoS One 8(4): e61537.

26. Zhang Y, Li MX, Wang H, Zeng Z, Li XM (2015) Metformin downregulates endometrial carcinoma cell secretion of IGF-1 and expression of IGF1R. Asian Pac J Cancer Prev 16(1): 221-225.

27. Xie Y, Wang JL, Ji M, Yuan ZF, Peng Z, et al. (2014) Regulation of insulin-like growth factor signaling by metformin in endometrial cancer cells. Oncol Lett 8(5): 1993-1999.

28. Coppola D, Saunders B, Fu L, Mao W, Nicosia SV(1999) The insulin-like growth factor 1 receptor induces transformation and tumorigenicity of ovarian mesothelial cells and down-regulates their Fas-receptor expression. Cancer Res 59: 3264-3270.

29. Gotlieb WH, Bruchim I, Gu J, Shi Y, Camirand A, et al. (2006) Insulinlike growth factor receptor I targeting in epithelial ovarian cancer. Gynecol Oncol 100(2): 389-396.

30. Beck EP, Russo P, Gliozzo B, Jaeger W, Papa V, et al. (1994) Identification of insulin and insulin-like growth factor I (IGF I) receptors in ovarian cancer tissue. Gynecol Oncol 53(2): 196-201.

31. Karasik A, Menczer J, Pariente C, Kanety H (1994) Insulin-like growth factor-I (IGF-I) and IGF-binding protein-2 are increased in cyst fluids of epithelial ovarian cancer. J Clin Endocrinol Metab 78(2): 271-276.

32. Sayer RA, Lancaster JM, Pittman J, Gray J, Whitaker R, et al. (2005) High insulin-like growth factor-2 (IGF-2) gene expression is an independent predictor of poor survival for patients with advanced stage serous epithelial ovarian cancer. Gynecol Oncol 96(2): 355-361.

33. Sayer RA, Lancaster JM, Pittman J, Gray J, Whitaker R, et al. (2005) High insulin-like growth factor-2 (IGF-2) gene expression is an independent predictor of poor survival for patients with advanced stage serous epithelial ovarian cancer. Gynecol Oncol 96(2): 355-361.

34. Spentzos D, Cannistra SA, Grall F, Levine DA, Pillay K, et al. (2007) IGF axis gene expression patterns are prognostic of survival in epithelial ovarian cancer. Endocr Relat Cancer 14(3): 781-790.

35. Brokaw J, Katsaros D, Wiley A, Lu L, Su D, et al. (2007) IGF-I in epithelial ovarian cancer and its role in disease progression. Growth Factors 25(5): 346-354.

36. Lukanova A, Lundin E, Toniolo P, Micheli A, Akhmedkhanov A, et al. (2002) Circulating levels of insulin-like growth factor-I and risk of ovarian cancer. Int J Cancer 101(6): 549-554.

37. Peeters PH, Lukanova A, Allen N, Berrino F, Key T, et al. (2007) Serum IGF-I, its major binding protein (IGFBP-3) and epithelial ovarian cancer risk: the European Prospective Investigation into Cancer and Nutrition (EPIC). Endocr Relat Cancer 14(1): 81-90.

38. Shah NG, Bhatavdekar JM, Doctor SS, Suthar TP, Balar DB, et al (1994) Circulating epidermal growth factor (EGF) and insulin-like growth factor-I (IGF-I) in patients with epithelial ovarian carcinoma. Neoplasma 41(5): 241-243.

39. Waksmański B, Dudkiewicz J, Kowalski T (2001) Changes in insulin-like growth factor I, 17-b-estradiol, and progesterone in postmenopausal women with benign and malignant ovarian tumours. Med Sci Monit 7(5): 919-923.

40. Serin IS, Tanriverdi F, Yilmaz MO, Ozcelik B, Unluhizarci K (2008) Serum insulin-like growth factor (IGF)-I, IGF binding protein
(IGFBP)-3, leptin concentrations and insulin resistance in benign and malignant epithelial ovarian tumors in postmenopausal women. Gynecol Endocrinol 24(3): 117-121.

41. Tworoger SS, Lee IM, Buring JE, Pollak MN, Hankinson SE (2007) Insulin-like growth factors and ovarian cancer risk: a nested casecontrol study in three cohorts. Cancer Epidemiol Biomarkers Prev 16(8): 1691-1695.

42. Tas F, Karabulut S, Serilmez M, Ciftci R, Duranyildiz D (2014) Clinical significance of serum insulin-like growth factor-1 (IGF-1) and insulin-like growth factor binding protein-3 (IGFBP-3) in patients with epithelial ovarian cancer. Tumour Biol 35(4): 3125-3132.

43. Ose J, Fortner RT, Schock H, Peeters PH, Onland-Moret NC, et al (2015) Insulin-like growth factor I and risk of epithelial invasive ovarian cancer by tumour characteristics: results from the EPIC cohort. Br J Cancer 112(1): 162-166.

44. Gianuzzi X, Palma-Ardiles G, Hernandez-Fernandez W, Pasupuleti V Hernandez AV, et al. (2016) Insulin growth factor (IGF) 1, IGF-binding proteins and ovarin cancer risk: A systematic review and metaanalysis. Maturitas 94: 22-29.

45. Tang J, Li J, Zeng G, Tang Y, Tian W, et al. (2013) Antisense oligonucleotide suppression of human IGF-1R inhibits the growth and survival of in vitro cultured epithelial ovarian cancer cells. J Ovarian Res 6(1): 71.

46. Eckstein N, Servan K, Hildebrandt B, Pölitz A, von Jonquières G, et al. (2009) Hyperactivation of the insulin-like growth factor receptor I signaling pathway is an essential event for cisplatin resistance of ovarian cancer cells. Cancer Res 69(7): 2996-3003.

47. Huang GS, Brouwer-Visser J, Ramirez MJ, Kim CH, Hebert TM, et al (2010) Insulin-like growth factor 2 expression modulates Taxol resistance and is a candidate biomarker for reduced disease-free survival in ovarian cancer. Clin Cancer Res 16(11): 2999-3010.

48. Benabbou N, Mirshahi P, Cadillon M, Soria J, Therwath A, et al. (2013) Hospicells promote upregulation of the ATP-binding cassette genes by insulin-like growth factor-I via the JAK2/STAT3 signaling pathway in an ovarian cancer cell line. Int J Oncol 43(3): 685-694.

49. Lee EJ, Mircean C, Shmulevich I, Wang HG, Liu J, et al. (2005) Insulinlike growth factor binding protein 2 promotes ovarian cancer cell invasion. Mol Cancer 4: 7.

50. Chakrabarty S, Kondratick L (2006) Insulin-like growth factor binding protein-2 stimulates proliferation and activates multiple cascades of the mitogen-activated protein kinase pathways in NIHOVCAR3 human epithelial ovarian cancer cells. Cancer Biol Ther 5(2): 189-197.

51. Kanety H, Kattan M, Goldberg I, Kopolovic J, Ravia J, et al. (1996) Increased insulin-like growth factor binding protein-2 (IGFBP-2) gene expression and protein production lead to high IGFBP-2 content in malignant ovarian cyst fluid. Br J Cancer 73(9): 1069-1073.

52. Wang H, Rosen DG, Wang H, Fuller GN, Zhang W, et al. (2006) Insulinlike growth factor-binding protein 2 and 5 are differentially regulated in ovarian cancer of different histologic types. Mod Pathol 19: 11491156.

53. Lancaster JM, Sayer RA, Blanchette C, Calingaert B, Konidari I, et al. (2006) High expression of insulin-like growth factor binding protein-2 messenger RNA in epithelial ovarian cancers produces elevated preoperative serum levels. Int J Gynecol Cancer 16(4): 15291535.

54. Flyvbjerg A, Mogensen O, Mogensen B, Nielsen OS (1997) Elevated serum insulin-like growth factor-binding protein 2 (IGFBP-2) and decreased IGFBP-3 in epithelial ovarian cancer: correlation with 
cancer antigen 125 and tumor-associated trypsin inhibitor. J Clin Endocrinol Metab 82(7): 2308-2313.

55. Huang YF, Cheng WF, Wu YP, Cheng YM, Hsu KF, et al. (2014) Circulating IGF system and treatment outcome in epithelial ovarian cancer. Endocr Relat Cancer 21(2): 217-229.

56. Baron-Hay S, Boyle F, Ferrier A, Scott C (2004) Elevated serum insulin-like growth factor binding protein-2 as a prognostic marker in patients with ovarian cancer. Clin Cancer Res 10(5): 1796-1806.

57. Lu L, Katsaros D, Wiley A, Rigault de la Longrais IA, Risch HA, et al. (2006) The relationship of insulin-like growth factor-II, insulinlike growth factor binding protein-3, and estrogen receptor-alpha expression to disease progression in epithelial ovarian cancer. Clin Cancer Res 12(4): 1208-1214.

58. Katsaros D, Yu H, Levesque MA, Danese S, Genta F, et al. (2001) IGFBP-3 in epithelial ovarian carcinoma and its association with clinico-pathological features and patient survival. Eur J Cancer 37(4): 478-485.

59. Dal Maso L, Augustin LS, Franceschi S, Talamini R, Polesel J, et al. (2004) Association between components of the insulin-like growth factor system and epithelial ovarian cancer risk. Oncology 67(3-4): 225-230.
60. Beltran PJ, Calzone FJ, Mitchell P, Chung YA, Cajulis E, et al. (2014) Ganitumab (AMG 479) inhibits IGF-II-dependent ovarian cancer growth and potentiates platinum-based chemotherapy. Clin Cancer Res 20(11): 2947-2958.

61. Chen HX, Sharon E (2013) IGF-1R as an anti-cancer target - trials and trubutions. Chin J Cancer 32(5): 242-252.

62. Brouwer-Visser J, Lee J, McCullagh K, et al. (2014) Insulin-like growth factor 2 silencing restores taxol sensitivity in drug resistant ovarian cancer. PLoS One 9(6): e100165.

63. Bitelman C, Sarfstein R, Bruchim I et al. (2013) IGF1R-directed targeted therapy enhances the cytotoxic effect of chemotherapy in endometrial cancer. Cancer Lett 335(1): 153-159.

64. Mendivil A, Zhou C, Bae-Jump VL et al. (2011) AMG 479, a novel IGF1-R antibody, inhibits endometrial cancer cell proliferation through disruption of the PI3K/Akt and MAPK pathways. Reprod Sci 18(9): 832-841.

65. Attias-Geva Z, Bentov I, Ludwig DL, Fishman A, Bruchim I, et al (2011) Insulin-like growth factor-I receptor (IGF-IR) targeting with monoclonal antibody cixutumumab (IMC-A12) inhibits IGF-I action in endometrial cancer cells. Eur J Cancer 47(11): 1717-1726.

\section{Your next submission with Juniper Publishers will reach you the below assets}

- Quality Editorial service

- Swift Peer Review

- Reprints availability

- E-prints Service

- Manuscript Podcast for convenient understanding

- Global attainment for your research

- Manuscript accessibility in different formats

( Pdf, E-pub, Full Text, Audio)

- Unceasing customer service

Track the below URL for one-step submission https://juniperpublishers.com/online-submission.php 